\title{
Water-Cooled Chiller Terintegrasi Heat Recovery System pada Industri Perhotelan di Bali
}

\author{
Made Sucipta ${ }^{1)^{*}}$, Ida Bagus Oka Jeve ${ }^{1)}$, Ketut Astawa ${ }^{1)}$ \\ 1)Program Studi Teknik Mesin - Universitas Udayana, Kampus Unud, Bukit Jimbaran, Bali, Indonesia
}

Naskah diterima 10/10/2020; direvisi 04/11/2020; disetujui 14/11/2020

doi: https://doi.org/10.24843/JEM.2020.v13.i02.p03

\begin{abstract}
Abstrak
Pengujian performa water-cooled chiller yang diintegrasikan dengan heat recovery system telah dilakukan pada suatu hotel di Bali. Setelah dilakukan commissioning, dilakukan pengujian selama 2 hari untuk mengetahui kesiapan komponen dalam operasionalnya. Koefisien prestasi yang menjadi acuan dalam penelitian ini digunakan untuk mengetahui performa sistem yang berkapasitas 275-ton refrigerasi yang dibedakan menjadi koefisien prestasi sistem refrigerasi dan koefisien prestasi sistem terintegrasi total. Pengambilan data dilakukan dengan selang waktu 8 jam mulai dari pukul 06.00, 14.00, dan 22.00 Wita setiap harinya. Kondisi ini didasarkan pada prediksi siklus perubahan penggunan energi di hotel yang mengikuti mulai dari sarapan, check-in hotel dan jam tidur. Dari hasil penelitian diperoleh bahwa dengan kondisi dan situasi hotel yang tidak terukur dengan tepat dan tingkat hunian hotel yang belum maksimal menghasilkan kapasitas refrigerasi yang besar di hari ke 2, tetapi hal ini juga diikuti oleh kebutuhan daya kompresor yang besar. Meskipun pada akhirnya koefisien prestasi sedikit lebih besar dari hari ke 1. Diperoleh pula bahwa kebutuhan laju perpindahan panas terbesar diperlukan pada pukul 22.00 Wita selama pengujian 2 hari tersebut. Hal ini kemungkinan dapat disebabkan karena kebutuhan air panas untuk tamu hotel mandi di malam hari. Secara umum, peningkatan koefisien prestasi masih memungkinkan terjadi bila terjadi peningkatan tingkat hunian hotel.
\end{abstract}

Kata kunci: water-cooled chiller, heat recovery system, koefisien prestasi, kapasitas refrigerasi, laju perpindahan panas

\begin{abstract}
Performance testing of water-cooled chiller integrated with a heat recovery system has been carried out at a hotel in Bali. After commissioning, testing is carried out for 2 days to determine the readiness of the components in operation. The coefficient of performance which is the reference in this study is used to determine the performance of the system with a capacity of 275 tons of refrigeration which is divided into the coefficient of performance of the refrigeration system and the coefficient of performance of the total integrated system. Data was collected with 8 hour intervals starting at 06.00, 14.00, and 22.00 Wita every day. This condition is based on the prediction of the cycle of changes in energy use in the hotel, which includes breakfast, hotel check-in and bedtime. From the research results, it was found that with the condition and situation of the hotel were not measured properly and the occupancy rate of the hotel which was not yet maximal resulted in a greater refrigeration capacity on the second day, but this was also followed by a large demand for compressor power. Although in the end the coefficient of performance was slightly larger than day 1. It was also found that the greatest need for heat transfer rate is required at 22.00 Wita during the 2-day test. This is possibly due to the need for hot water for hotel guests to shower at night. In general, an increase in the coefficient of performance is still possible if there is an increase in hotel occupancy rates.
\end{abstract}

Keywords: water-cooled chiller, heat recovery system, coefficient of performance, refrigeration capacity, heat transfer rate.

\section{Pendahuluan}

Bali sebagai daerah tujuan wisata, merupakan pulau yang sering dikunjungi oleh wisatawan domestik dan manca negara telah banyak menyiapkan sarana dan prasarana yng sangat menunjang industri pariwisata. Hotel sebagai tempat beristirahatnya para wisatawan tidak terkecuali sudah memanjakan dengan fasliitas yang diberikan termasuk kenyamanan termal baik di dalam maupun di luar kamar hotel.

Salah satu upaya menciptakan kenyaman termal adalah dengan menggunakan sistem pengkondisian udara (AC) central yang berbasis chiller, terutama pada hotel-hotel besar. Umumnya chiller menerapkan sistem refrigerasi yang berbasis sistem kompresi uap, dimana refrigeran, fluida yang mengalir dalam sistem refrigerasi, disirkulasikan dalam sistem dengan cara ditekan dan dihisap oleh kompresor [1]. Kalau dilihat dari kapasitas chiller terpasang yang umumnya berukuran besar maka sesuai siklus kompresi uap, panas yang terbuang melalui unit kondensor akan terbuang cukup besar juga.

Disisi lain, kenyamanan wisatawan selama berada di hotel tidak hanya tergantung pada sistem pendinginan ruangan tetapi dapat juga memerlukan fasilitas lain, seperti misalnya kebutuhan air panas untuk mandi. Bagi pengelola hotel, kebutuhan air panas ini juga penting untuk bagian dapur ataupun dibagian laundry. Di beberapa hotel, kebutuhan air panas ini disediakan melaui instalasi boiler yang tentu memerlukan biaya operasional tambahan.

Melihat teknologi yang berkembang saat ini, chiller yang kapasitas besar ini akan dapat dimanfaatkan energi panas yang terbuang dari kondensor tersebut sebagai sumber energi untuk menghasilkan air panas. Pemanfaatan heat recovery system (HRS) dapat menjadi salah satu solusi sebagai sumber energi untuk pemanas air. 
Beberapa studi untuk meningkatkan coefficient of performance (COP) sistem water-cooled chiller telah dilakukan dengan melakukan beberapa kombinasi komponen sistem [2], dimana COP sistem yang lebih tinggi dapat diperoleh dengan mengoperasikan komponen sistem seperti chiller, cooling tower, dan pompa dengan jumlah yang seimbang. Studi tentang perhitungan COP sistem water-cooled chiller juga pernah diteliti dengan menggunakan model artificial neural network (ANN) [3]. Pada sistem AC central, komponen chiller akan memerlukan proporsi energi yang paling besar jika dibandingkan dengan komponen sistem lainnya [4]. Hal ini tentu akan dapat dioptimalkan kalau panas terbuang sistem dapat dimanfaatkan melalui HRS. Kajian tentang sistem refrigerasi yang dikombinasikan dengan HRS sudah pernah diteliti pada AC split [5], dimana dengan modifikasi sistem ini akan dapat dihasilkan air panas. Tetapi belum banyak kajian yang membahas bagaimana HRS yang dikombinasikan pada chiller.

Bertolak pada hal tersebut diatas, pada penelitian ini akan dilakukan analisis performa pada water-cooled chiller yang diintegrasikan dengan HRS yang baru terpasang pada salah satu hotel di Bali. Sistem ini diketahui memiliki kapasitas sebesar 275-ton refrigerasi (TR). Pengujian dilakukan pada sistem chiller tersebut setelah dilakukan commissioning untuk memastikan bahwa setiap bagian dari unit chiller dapat beroperasi sesuai dengan fungsinya.

\section{Metode Penelitian}

Refrigerasi adalah proses pendinginan arftifisial sebuah ruangan, merupakan sistem untuk menurunkan dan/atau menjaga suhu tetap dibawah suhu lingkungan ketika panas yang dibuang memiliki temperatur yang lebih tinggi. Panas dibuang dari ruangan yang memiliki suhu rendah dan ditransfer menuju lingkungan yang memiliki suhu tinggi.

Refrigerasi berdasarkan motode yang digunakan dapat diklasifikasikan menjadi refrigerasi termoelektrik, magnetik, non-siklik dan refrigerasi siklik [5]. Refrigerasi bekerja menggunakan media refrigeran, dimana pada studi ini refrigeran yang digunakan adalah refrigeran $\mathrm{R}$ 410A. Pada sistem chiller terintegrasi HRS, alat penukar panas tipe pelat dengan aliran berlawanan terintegrasi pada sisi keluaran kompresor yang digunakan untuk mentransfer panas dari refrigeran menuju air. Skema sistem water-cooled chiller yang terintegrasi HRS ditunjukkan pada Gambar 1.

Pengambilan data operasional chiller dilakukan selama 2 hari setiap pukul $06.00,14.00$, dan 22.00 Wita yang menggambarkan perwakilan aktivitas harian hotel, mulai persiapan sarapan, check-in hotel, dan jam tidur malam. Pada penelitian ini beberapa termokopel dipasang pada beberapa posisi dan penggunaan ultrasonic flow meter untuk mengukur debit aliran, seperti ditunjukkan pada Gambar 2. Pada evaporator, perhitungan kapasitas refrigerasi, $q_{c h}$, dihitung dari laju pendinginan di laju alir air chiller, $\dot{V}_{c h}$, dan suhu masuk air, $T_{c h, i}$, dan keluar air, $T_{c h, o}$. Sedangkan pada HRS, laju perpindahan panas, $q_{h w}$, dihitung dari laju alir air masuk ke alat penukar kalor, $T_{h w, i}$, dan suhu keluar alat penukar kalor, $T_{h w, o}$, serta laju alir air di HRS, $\dot{V}_{h w}$. Untuk data lainnya diperoleh dari referensi yang ada.

Perhitungan koefisien prestasi (COP) dilakukan dengan membedakan $C O P_{R}$ yang menunjukkan koefisien prestasi pada sistem refrigerasi, dan ${ } O P_{S}$ yang menunjukkan koefisien prestasi sistem chiller terintegrasi HRS. Daya total yang bekerja pada sistem chiller terintegrasi HRS dihtiung dengan menjumlahkan semua daya yang diperlukan sistem, $W_{s}$, yaitu terdiri dari daya pada kompresor, $W_{c p}$, pompa chiller, $W_{c h}$, pompa HRS, $W_{h w}$, pompa cooling tower, $W_{c t}$, dan kipas pendingin cooling tower, $W_{f n}$. Daya-daya tersebut diukur langsung dari daya listrik yang diperlukan pada sistem. Persamaan koefisien prestasi tersebut adalah:

$$
\operatorname{COP}_{R}=\frac{q_{c h}}{W_{c p}}
$$

dan,

$$
C O P_{S}=\frac{q_{c h}+q_{h w}}{W_{S}}
$$

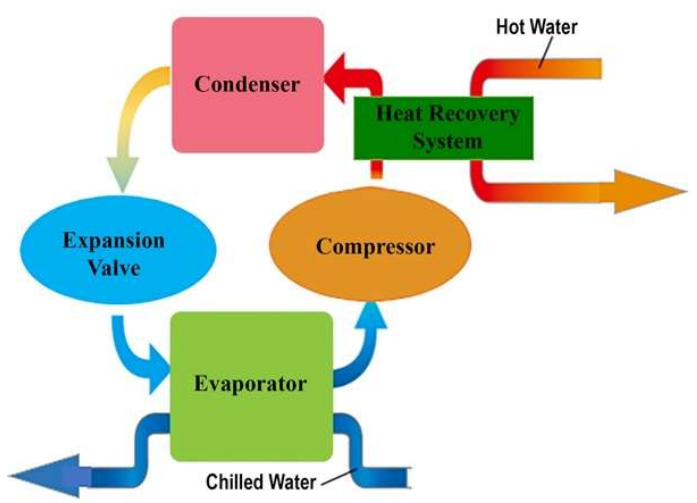

Gambar 1. Skema water-cooled chiller terintegrasi HRS

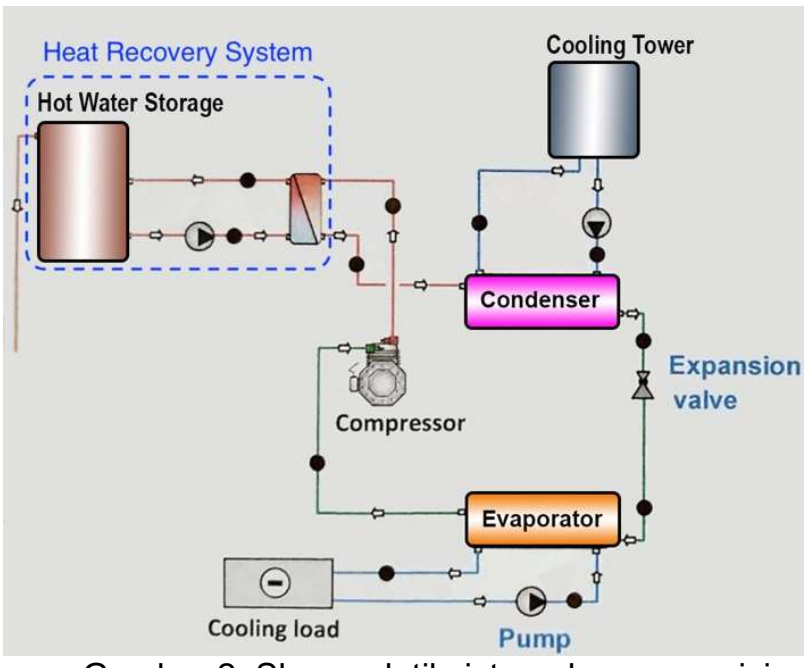

Gambar 2. Skema detil sistem dengan posisi penempatan alat ukur

\section{Hasil dan Pembahasan}

Penelitian ini dilakukan dalam kondisi operasional hotel yang normal, dimana chiller sudah beroperasi dalam beberapa hari sebelumnya. Dari hasil pengukuran diperoleh bahwa suhu air chiller yang masuk dan keluar evaporator tidak banyak berubah, berada disekitar $3,3^{\circ} \mathrm{C}$, seperti dapat dilihat pada Tabel 1. Akan tetapi perubahan cukup besar dapat kita amati pada hari ke 2, khususnya pada pukul 22.00 Wita 
dimana selisih suhu yang diperoleh adalah sebesar $4,0^{\circ} \mathrm{C}$. Demikian pula pada suhu air HRS yang masuk dan keluar alat penukar panas yang dilalui oleh refrigeran keluar dari kompresor. Pada Tabel 1 dapat kita amati ada selisih yang kecil juga pada hari ke 2 pukul 14.00 Wita sebesar $11,5^{\circ} \mathrm{C}$ dibandingkan selisih pada waktu lainnya yang berada dikisaran diatas $14^{\circ} \mathrm{C}$.

Tabel 1. Data hasil pengukuran suhu dan laju alir air.

\begin{tabular}{ccrrrrrrr}
\hline \multirow{2}{*}{ Data } & \multirow{2}{*}{ Satuan } & \multicolumn{3}{c}{ Hari ke 1 (Wita) } & \multicolumn{3}{c}{ Hari ke 2 (Wita) } & Rata- \\
\cline { 3 - 7 } & & 06.00 & 14.00 & 22.00 & 06.00 & 14.00 & 22.00 & rata \\
\hline$T_{c h, o}$ & ${ }^{\circ} \mathrm{C}$ & 8,8 & 7,2 & 8,0 & 7,5 & 7,1 & 7,7 & 7,7 \\
$T_{c h, i}$ & ${ }^{\circ} \mathrm{C}$ & 11,7 & 10,1 & 11,0 & 11,0 & 10,4 & 11,7 & 11,0 \\
$\dot{V}_{c h}$ & $\mathrm{~m}^{3} / j a m$ & 167 & 167 & 167 & 167 & 167 & 167 & 167 \\
$T_{h w, o}$ & ${ }^{\circ} \mathrm{C}$ & 60,0 & 59,3 & 60,0 & 60,0 & 58,0 & 60,0 & 59,6 \\
$T_{h w, i}$ & ${ }^{\circ} \mathrm{C}$ & 45,6 & 44,9 & 45,1 & 45,6 & 46,5 & 45,1 & 45,5 \\
$\dot{V}_{h w}$ & $m^{3} / j a m$ & 5,1 & 5,1 & 5,0 & 5,1 & 5,0 & 5,1 & 5,1 \\
\hline
\end{tabular}

Tabel 2. Kapasitas refrigerasi, laju perpindahan panas pada HRS dan daya yang diperlukan sistem.

\begin{tabular}{|c|c|c|c|c|c|c|c|c|}
\hline \multirow{2}{*}{ Hasil } & \multirow{2}{*}{ Satuan } & \multicolumn{3}{|c|}{ Hari ke 1 (Wita) } & \multicolumn{3}{|c|}{ Hari ke 2 (Wita) } & \multirow[t]{2}{*}{$\begin{array}{l}\text { Rata- } \\
\text { rata }\end{array}$} \\
\hline & & 06.00 & 14.00 & 22.00 & 06.00 & 14.00 & 22.00 & \\
\hline$q_{c h}$ & $k W$ & 563,7 & 563,9 & 583,3 & 680,5 & 641,7 & 777,8 & 635,2 \\
\hline$q_{h w}$ & $k W$ & 83,3 & 82,3 & 85,3 & 83,1 & 65,5 & 86,0 & 80,9 \\
\hline$W_{c p}$ & $k W$ & 134,7 & 132,5 & 119,1 & 151,9 & 142,0 & 156,6 & 139,5 \\
\hline$W_{c h}$ & $k W$ & 31,4 & 31,5 & 31,4 & 31,0 & 31,4 & 31,6 & 31,4 \\
\hline$W_{h w}$ & $k W$ & 2,6 & 2,6 & 2,6 & 2,5 & 2,6 & 2,6 & 2,6 \\
\hline$W_{c t}$ & $k W$ & 17,8 & 17,9 & 17,8 & 17,3 & 17,8 & 18,0 & 17,8 \\
\hline$W_{f n}$ & $k W$ & 11,8 & 11,8 & 11,7 & 11,8 & 11,8 & 11,7 & 11,8 \\
\hline$W_{S}$ & $k W$ & 198,3 & 196,1 & 182,6 & 214,6 & 205,6 & 220,6 & 203,0 \\
\hline
\end{tabular}

Selisih suhu pada air chiller yang masuk dan keluar evaporator akan berdampak langsung pada kapasitas refrigerasi. Seperti dapat kita amati, bahwa kapasitas refrigerasi pada hari ke 2 pengujian menunjukkan hasil yang lebih besar dibandingkan dengan hari pertama. Dan, dapat kita amati pula bahwa kapasitas refrigerasi terbesar diperoleh pada hari ke 2 pukul 22.00 Wita, yaitu sebesar $777,8 \mathrm{~kW}$. Hal ini utamanya disebabkan karena diperoleh selisih suhu air chiller yang terbesar seperti dibahas sebelumnya. Kalau kita amati daya kompresor yang diperlukan pada sistem, dimana pada hari ke 2 juga diperlukan daya kompresor yang lebih besar dibandingkan dengan hari ke 1. Hal ini dapat menunjukkan bahwa kerja kompresor ini adalah untuk mengimbangi kapasitas refrigerasi pada hari ke 2 yang juga besar. Berbeda dengan daya listrik yang diperlukan pada komponen-komponen yang lain yang cenderung hampir sama selama pengujian. Pada akhirnya daya kompresor yang besar pada hari ke 2 tersebut akan mempengaruhi langsung kebutuhan total daya listrik yang diperlukan pada sistem, seperti dapat dilihat pada Tabel 2 bagian bawah, yaitu diatas $200 \mathrm{~kW}$.

Demikian pula untuk laju perpindahan panas yang terjadi pada HRS karena terjadi selisih suhu terkecil pada hari ke 2 pukul 14.00 Wita, maka diperoleh pula laju perpindahan panas terkecil yaitu sebesar $65,5 \mathrm{~kW}$. Kondisi ini secara teknis susah dijelaskan karena melihat kondisi dan situasi hotel pada hari-hari tersebut tidak dapat diketahui secara pasti perputaran orangorang didalam hotel, meskipun dapat diperoleh data bahwa tingkat hunian hotel belum mencapai maksimal. Akan tetapi, kalau diperhatikan pengujian selama 2 hari ini bahwa pada pukul 22.00 Wita terjadi peningkatan laju perpindahan panas pada HRS. Hal ini cenderung dapat disebabkan karena pada malam hari kebutuhan air panas untuk mandi bagi tamu-tamu hotel menjadi meningkat sehingga dapat diperoleh hasil seperti tersebut.

Dari hasil-hasil perhitungan diatas dapat kita cermati pula bahwa pada hari ke 2 terjadi peningkatan kapasitas refrigerasi dibanding pada hari ke 1, akan tetapi kalau dilihat daya kompresor yang diperlukan juga menunjukkan kebutuhan listrik yang besar pula pada hari tersebut. Sesuai perhitungan dengan menggunakan Pers. (1) maka dapat kita hitung bahwa tidak diperoleh peningkatan koefisien prestasi yang besar, seperti ditunjukkan pada Tabel 3. Memang koefisien prestasi tertinggi diperoleh sebesar 5,0 pada hari ke 2 pukul 22.00 Wita yang dapat terjadi karena kapasitas refrigerasi yang tertinggi pula selama pengujian. Seperti dapat kita amati pula dari Tabel 3 , koefisien prestasi refrigerasi berada pada kisaran $4,2-$ 5,0 dengan rata-rata sebesar 4,6.

Tabel 3. COP refrigerasi dan total sistem terintegrasi

\begin{tabular}{cccccccc}
\hline \multirow{2}{*}{ COP } & \multicolumn{3}{c}{ Hari ke 1 (Wita) } & \multicolumn{3}{c}{ Hari ke 2 (Wita) } & Rata- \\
\cline { 2 - 8 } & 06.00 & 14.00 & 22.00 & 06.00 & 14.00 & 22.00 & rata \\
\hline COP $_{c h}$ & 4,2 & 4,3 & 4,9 & 4,5 & 4,5 & 5,0 & 4,6 \\
COP $_{S}$ & 3,3 & 3,3 & 3,7 & 3,6 & 3,4 & 3,9 & 3,5 \\
\hline
\end{tabular}

Secara total sistem, water-cooled chiller yang terintegrasi HRS ini memberikan koefisien prestasi ratarata sebesar 3,5. Dari Tabel 3 dapat diperoleh data bahwa koefisien prestasi sistem terbesar diperoleh sebesar 3,9 yang terjadi pada hari ke 2 pukul 22.00 Wita. Menarik untuk dicermati pula bahwa koefisien prestasi terbesar pada hari ke 1 pun diperoleh pada pukul 22.00 Wita yaitu sebesar 3,7. Hal ini sejalan dengan peningkatan laju perpindahan panas pada HRS yang terjadi pada waktu-waktu tersebut.

Melihat kondisi diatas, maka dapat diprediksi bahwa apabila terjadi peningkatan jumlah hunian hotel akan memungkinkan pula terjadi peningkatan koefisien prestasi sistem, karena melihat kondisi selama pengujian tampak bahwa koefisein prestasi belum maksimal.

\section{Simpulan}

Sistem pendinginan water-cooled chiller yang diaplikasikan di salah satu hotel di Bali telah berhasil diintegrasikan dengan heat recovery system untuk pemenuhan kebutuhan air panas. Selama penelitian selama dua hari dengan tingkat hunian hotel yang normal sistem terintegrasi ini telah mampu berjalan dengan baik tanpa adanya kendala teknis. Meskipun kapasitas terpasang belum digunakan secara maksimal, tetapi hasil pengujian pada waktu-waktu puncak penggunaan sistem pendinginan dan/atau pemanasan di hotel menunjukkan bahwa hasil koefisien prestasi yang masih tinggi. Secara total sistem masih memungkinkan untuk meningkatkan koefisien prestasi yang diperoleh kalau sistem ini dioperasikan dengan beban yang lebih besar, dalam hal ini apabila terjadi tingkat hunian hotel yang lebih besar.

\section{Ucapan Terima Kasih}

Ucapan terima kasih disampaikan kepada pihak hotel dan kontraktor yang telah memfasilitasi penelitian ini. 


\section{Daftar Pustaka}

[1] C.P. Arora, Refrigeration and Air Conditioning, New Delhi: Tata McGraw-Hill, 2000.

[2] F.W. Yu, and W.T. Ho, Analysis of Chiller System Performance with Different Component Combinations, Applied Thermal Engineering, 2019.

[3] C. Tian, Z. Xing, X. Pan, and Y. Tian, A Method for COP Prediction of an On-site Screw Chiller Applied in Cinema, International Journal of Refrigeration, 2018.

[4] L.-r. Liu, J.-j. Gu, and J. Liu, Analysis of Operational Energy Intensity for Central Air Conditioning System with Water-cooled Chiller by Decomposition Method, Energy and Buildings, 2015.

[5] G. Gong, F. Chen, H. Su, and J. Zhou, Thermodynamic Simulation of Condensation Heat Recovery Characteristics of a Single Stage Centrifugal Chiller in a Hotel, Applied Energy, 2012.

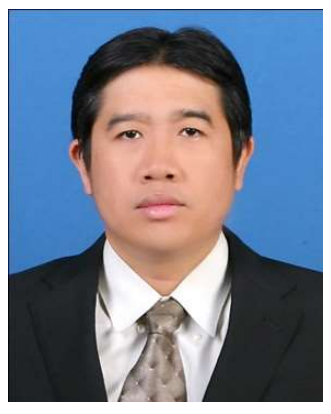

Made Sucipta menyelesaikan studi program sarjana dan magister di Jurusan Teknik Mesin, Institut Teknologi Sepuluh Nopember di Surabya pada tahun 1998 dan 2001 dengan bidang konsentrasi konversi/teknologi energi.

Pendidikan program doktor diselesaikan pada tahun 2007 di Shibaura Institute of Technology di Tokyo, Jepang, dengan bidang konsentrasi teknologi energi baru dan terbarukan. 